\title{
THE PRACTICE AND DETERMINING FACTORS OF VOLUNTARY GRAPHICS DISCLOSURE IN LOCAL GOVERNMENT FINANCIAL STATEMENTS IN INDONESIA
}

\author{
AGUNG NUR PROBOHUDONO1, * \\ SUPRIYANTO SUPRIYANTO ${ }^{1}$ \\ ESTETIKA MUTIARANISA KURNIAWATI ${ }^{1}$
}

Received: 29 Jul 2019/ Revised: 2 July 2020, 7 December 2020 / Accepted: 30 December 2020

(C) 2021 Faculty of Business and Accountancy, University of Malaya. All rights reserved.

\begin{abstract}
A B S T R A C T
Research aim: This study aims to measure the extent and the determinants of voluntary graphics disclosure in Laporan Keuangan Pemerintah Daerah (LKPD) or Local Government Financial Statements in Indonesia.

Design/ Methodology/ Approach: This study used 197 audited LKPD in Indonesia, comprising 155 regency governments and 32 district governments. The financial statements of these 197 local governments were examined to measure the extent of voluntary graphics disclosure and investigate the potential determinants of voluntary graphics disclosure. This study used multiple regression analysis to examine the determinants (performance, level of dependency, location, education background, and competency) of voluntary graphics disclosures.

Research findings: The results indicate a low extent of voluntary graphics disclosure in the LKPD in Indonesia. The average voluntary graphics disclosure rate is $44.88 \%$, demonstrating a lack of usage of voluntary graphics disclosure. The results also indicate that only performance has an insignificant effect on the extent of voluntary graphics disclosure.

Practitioner/ Policy implication: The findings regarding voluntary graphics disclosure in LKPD should be of concern to regulatory authorities and standard setters in Indonesia.

Research limitation: This study focuses on measuring the extent and the determinants of voluntary graphics disclosure practices among 197 local governments in Indonesia. Hence, the sample of this study is limited to the local governments employing graphics in providing information in their financial statements for the year 2015.

Keywords: Local Government Financial Statements, Local Government, Voluntary Graphics Disclosure

Type of article: Research paper

JEL Classification: H70
\end{abstract}

\section{Introduction}

One of the aspects of reform that continually attracts the Indonesian government's attention is government system reform. This phenomenon is evidenced by the continuous revisions of the constitution on local

\footnotetext{
1 Accounting Study Program, Universitas Sebelas Maret, Jln. Ir. Sutami No.36, Kentingan, Kec. Jebres, Kota Surakarta, Jawa Tengah 57126, Indonesia. *Corresponding author, e-mail: anprobohudono@staff.uns.ac.id; mustdownnow@gmail.com
} 
governments, with the latest revision done on Act Number 9 of 2015 on Local Government. This revision paves the way for a new government system from a centralised to a decentralised system. The decentralisation and local autonomy policy applied in some developing countries, including Indonesia, exists in three forms: fiscal decentralisation, administrative decentralisation, and political decentralisation (Litvack \& Seddon, 2002).

With the implementation of local autonomy, other than having rights and power to manage their regencies, local governments are obliged to document their reports in implementing the local autonomy. Drawing on Regulation No. 23 of 2014, among the reports that local governments need to document are the financial statements. The Laporan Keuangan Pemerintah Daerah (LKPD) or Local Government Financial Statements audited by the Indonesian Supreme Audit Institution, have to be reported to the local people within six months after the end of the budgeting year. The reporting mechanism aims to realise the accountability and transparency of local government financial management (Mulyana, 2006). In addition, financial reporting is crucial information for users in making decisions (Diamond, 2002).

However, during the International Symposium on the Future for Indonesian Government Financial Reporting, the Indonesian Vice Minister of Finance stated that the utilisation of information in the financial statements by executives is still low. This situation might be influenced by several factors, including financial report management, the users of financial reports, and the presentation of financial statements. Empirical findings show that accountable LKPD may provide beneficial information (Agustijanti, 2016), but financial statements that are too complex may not interest the users (Rezaee \& Porter, 1993). Therefore, previous research reveals that the presentation of financial statements affects the importance of the reports for users (Bandari \& Rohman, 2011; Mulyana, 2006; Sanjaya et al., 2014; Saputra, 2012; Steccolini, 2004).

In network settings, public sector organisations are agents in a relationship with citizens. As the ultimate principals, citizens are interested in information that helps them monitor the agents and assess the efficiency and effectiveness of public spending, leading to the expectation that organisations are more likely to disclose voluntary information with the most qualitative presentation. Information disclosure is often the main vehicle for accountability and information asymmetry reduction between public officials and citizens, and therefore, it reduces the agency costs.

The information presented in LKPD should adhere to Government Regulation No. 71 Year 2010 on Government Accounting Standards. According to the regulation, there is no mandatory format for the presentation of information in the financial statements; information may be presented by the inclusion of a list, table, narration, graphic, schedule, or other forms that may ease user interpretation. In this regard, the presentation of information in 
LKPD is characterised by voluntary disclosure. Of all the information display methods, graphics are the most examined, particularly in the private sector due to its escalating use in the annual reports in developed countries (Beattie \& Jones, 2002).

Horton (1993) indicated that for the private sector, with the diverse and international investment environment, using graphics can shorten the distance between languages and cultures. Ruchti and Wasserman (1983) stated that public companies have to view themselves as publishers, assuming the annual report is a periodical. Therefore, the annual reports require "graphic ignition" to make them successful periodicals. Previous studies believe that the use of graphics can facilitate the flow of accounting information (Cunningham, 1990; Holmes, 1984; Hussey, 1990). Hence, graphics are a key communication feature to a certain extent and one that companies can effectively utilise to provide relevant financial and management information (Huang et al., 2008). Since graphs reduce the time and effort that senior executives and managers use in analysing tables, they are demanding financial information in the graphic form generated by computers (Sullivan, 1988).

A graphical presentation of financial and non-financial information is a relatively low-cost means by which companies can enrich their annual reports. (Frownfelter-Lohrke \& Fulkerson, 2001). Beattie and Jones (2002) suggest that the use of graphics is an excellent tool for communicating financial information due to the visual effects of graphics, allowing the viewer to directly and immediately understand the content of the information. Additionally, the use of graphics as a mode of reporting financial information can also facilitate the speed of the viewer's ability to observe any discrepancies or other significant phenomena (Vessey, 1991). However, there is no clear guidance on the usage of financial graphics for information disclosure, even though graphs have many benefits (Huang et al., 2008).

Nonetheless, research regarding the deployment of graphics in LKPD remains under-explored, indicating that the current research is of paramount importance as it is the one that initially investigates this research variable. The graphics method continues to be widely used in presenting information in LKPD. One factor that allows the use of graphics in the financial statements is the performance of the organisation. An organisation with good performance prefers to use more graphics to display information (Ali \& Saad, 2006; Andrenossa \& Sukartha, 2014; Dilla \& Janvrin, 2010; Mather et al., 1998; Saha \& Akter, 2013; Uyar, 2009). However, some prior studies show no relationship between performance and the graphical presentation of information (Guddal, 2016; Mather et al., 1996; Purwanto, 2010; Saad et al., 2011; Uyar, 2011; Warganegara et al., 2013). 
The financial capacity of a local government is dependent on funding from the central government. Some previous studies found a significant positive correlation between local government dependency and the presentation of information in LKPD (Martani et al., 2014; Puspita \& Martani, 2012; Robbins \& Austin, 1986), but others revealed a different result (a negative correlation) (Hendriyani \& Tahar, 2015; Patrick, 2007; Setyaningrum \& Syafitri, 2012). In fact, some researchers found no evidence of a correlation between the two variables (Hilmi \& Martani, 2012; Ingram \& DeJong, 1987; Lesmana, 2010; Martani \& Lestari, 2010; Narulitasari, 2016; Setyowati, 2016). Furthermore, a local government's office location may positively influence the choice of information presented in its LKPD. The local governments in Java Island were found to be better at presenting information in their LKPD (Arifin et al., 2016; Narulitasari, 2016), but other research found no difference between the local governments located on the island and those located beyond the island (Pujiyanti, 2011; Suhardjanto \& Yulianingtyas, 2011).

Another factor that may influence the information presented in LKPD is the characteristics of the regent or mayor. Regents or mayors are accorded supreme power to manage the financial statements of the regency governments or district governments (Regulation of the Minister for Home Affairs 21/2011, 2011). The statement above is supported by studies that proved the existence of a correlation between the level of education of a regent or mayor and the presentation of financial statements (Bamber et al., 2010; Finkelstein \& Hambrick, 1996; Hambrick \& Mason, 1984; Wiersema \& Bantel, 1992), but others found no such correlation between the variables (Patrick, 2007; Prayitno, 2012).

The educational background of regents or mayors is also said to be a factor that impacts the disclosure in financial statements (Bamber et al., 2010; Kharis \& Suhardjanto, 2012; Lewis et al., 2013). However, other research revealed no correlation between the variables (Suhardjanto \& Miranti, 2009; Suhardjanto \& Permatasari, 2010) nor with the disclosure of information in the financial statements (Haniffa \& Cooke, 2002; Setyaningrum \& Syafitri, 2012).

Drawing on the inconsistent findings of the previous studies, this study aims to measure the extent of voluntary graphics disclosure and the determinants of voluntary graphics disclosure practices in the LKPD in Indonesia. Subsequently, this paper presents the literature review and research hypotheses in Section 2. Section 3 discusses the research methodology adopted in this study. Section 4 presents the data analyses on voluntary graphics disclosure and discusses the findings. Section 5 concludes the study with the scope for future research, implications, and recommendations. 


\section{Literature Review}

The agency theory is based on the fundamental premise that managers act out of self-interest and do not always protect shareholders' interests. According to Jensen and Meckling (1976), a principal-agent relationship refers to a contract under which the principal engages another party (the agent) to perform some service on their behalf which involves delegating some decision-making authority to the agent. The agency problem may happen to all types of organisation (Zimmerman, 1977), either from the private or public sector. This problem may be caused by a conflict of interest or information asymmetry. Disclosure can be regarded as a means to confer more assurance to shareholders that the company is being appropriately managed via enhanced transparency and accountability (Craswell \& Taylor, 1992; McKinnon \& Dalimunthe, 1993). Prior research findings indicate that voluntary disclosure has been identified as an important mechanism for reducing the agency problem (Martínez-Ferrero et al., 2016, 2018; Peters \& Romy, 2013).

The Government Accounting Standard Statement No. 1 defines the financial report as a report stating the financial position, financial condition, and numerous financial transactions entered by an organisation during the financial period. The information presented in the LKPD is subject to legal rule so that the purposes of the financial report can be attained. All the regulations demand that the information presented in the LKPD should comply with the Standar Akuntansi Pemerintahan (SAP) or Government Accounting Standard. The SAP regulation states that the information displayed in LKPD is based on voluntary disclosure.

The agent can use graphics to disclose information in the financial statements. The use of graphics may present succinct and comprehensive quantitative data. Research findings show some benefits of using graphics in the report: it is friendly-user and more interpretable than tables (Beattie \& Jones, 1994; Saptodewo, 2014; Smith \& Bain, 1987), it helps speeds up the decision making (Huang et al., 2008; Uyar, 2009), it helps summarise information (Amer, 2002; Chan, 2001; Frownfelter-Lohrke \& Fulkerson, 2001; Fulkerson et al., 1999), and it presents information more effectively (Wilson \& Stanton, 1996). In addition, the use of graphics in the financial report helps users understand the information (Beattie \& Jones, 1997, 2008; FrownfelterLohrke \& Fulkerson, 2001).

Several types of research have been done on the factors affecting the use of graphics in the private sector's financial report. Mather et al. (1996) found no link between the graphical presentation of information and firm performance. Some prior studies show that organisations with good performance prefer to use more graphics for information disclosure (Ali \& Saad, 2006; Andrenossa \& Sukartha, 2014; Dilla \& Janvrin, 2010; Mather et al., 1998; Saha \& Akter, 2013; Uyar, 2009). However, similar research focusing on the government sector 
remains scarce. Hence, it can be said that the current research is a pioneer in investigating the factors and practice of voluntary graphics disclosure in the financial reports of local governments.

From the agency theory perspective, the agent discharges their responsibility to the principal through an annual report to show their achievements. Company managers use graphics to demonstrate their performance through profitability (Beattie \& Jones, 1994; Steinbart, 1989). The companies with greater profitability increases tend to use graphics to present information (Ali \& Saad, 2006; Andrenossa \& Sukartha, 2014; Dilla \& Janvrin, 2010; Mather et al., 1998; Saha \& Akter, 2013; Uyar, 2009). Thus, the first hypothesis of this study is as follows.

H1: The performance of the local government has a positive effect on voluntary graphics disclosure.

Intergovernmental revenue, one of the local governments' revenues, comes from central government transfer funds (Patrick, 2007; Robbins \& Austin, 1986). The central government allocates some funding for general purposes to help the local governments meet their needs.

The amount of the Dana Alokasi Umum (DAU) or General Allocation Fund provided to each regional government is calculated based on a formula determined by the central government. Regions that have low fiscal capacity will get a greater supply of the DAU. This notion suggests that the greater the DAU received by a local government, the higher its regional dependence on the central government. A high level of dependency shows that the local government is not financially independent (Halim, 2002). Regions that are not financially independent are increasingly unable to innovate, including in graphics voluntary disclosure. Prior research shows a negative link between the level of dependency on the central government and the extent of disclosure in LKPD (Hendriyani \& Tahar, 2015; Patrick, 2007; Setyaningrum \& Syafitri, 2012). Hence, the second hypothesis to be explored.

H2: The level of dependency of the local government has a negative effect on voluntary graphics disclosure.

Throughout the past three decades, the development of all sectors in Indonesia centred on Java Island, which has caused disparities or gaps between the local governments in Java and other islands. Besides, such a situation brings about gaps in human resources, which are better in Java than in the non-Javanese islands. The high quality of human resources together with the good quality of infrastructure and the economy results in a much better presentation of the financial reports in Java than in other islands. Some previous studies found evidence that the information presented in the LKPD 
from the island of Java is much better than that from other islands (Arifin et al., 2016; Narulitasari, 2016). Hence, the hypothesis designed is as follows.

H3: The location of the local government has a positive effect on voluntary graphics disclosure.

The level of education relates to the capacity for good information management (Hitt \& Tyler, 1991; Wally \& Baum, 1994). This variable has been found to have a positive correlation with innovation acceptance (Bantel \& Jackson, 1989; Finkelstein \& Hambrick, 1996; Hambrick \& Mason, 1984; Kimberly \& Evanisko, 1981; Sebaa et al., 2009; Wiersema \& Bantel, 1992). Voluntary graphics disclosure is one of the innovations made by local governments in presenting information in the LKPD. Prior research reveals that the education level of the local government head correlates significantly with the level of innovation (Bamber \& McMeeking, 2010; Finkelstein \& Hambrick, 1996; Hambrick \& Mason, 1984; Sebaa et al., 2009; Wiersema \& Bantel, 1992). Therefore, the following hypothesis is constructed.

H4: The education level of the local government head has a positive effect on voluntary graphics disclosure.

The capacity of the manager can be a determining factor for the practice of information disclosure. A manager with an education background in accounting and business tends to reveal more information to recover their company's fame (Haniffa \& Cooke, 2002). The logic behind this is that the local government manager who has an accounting and economic education background will be better able to implement the accounting standards in presenting information in the LKPD. Previous research shows that the manager's education background has a positive correlation with the disclosure of information by a company (Kharis \& Suhardjanto, 2012; Lewis et al., 2013) and voluntary disclosure in the financial statements (Bamber et al., 2010). Hence, this research forms the following hypothesis.

H5: The competency of the local government head has a positive effect on voluntary graphics disclosure.

\section{Methodology}

This research used secondary data derived from the audited reports of LKPD for the year of 2015 for data of DAU. 


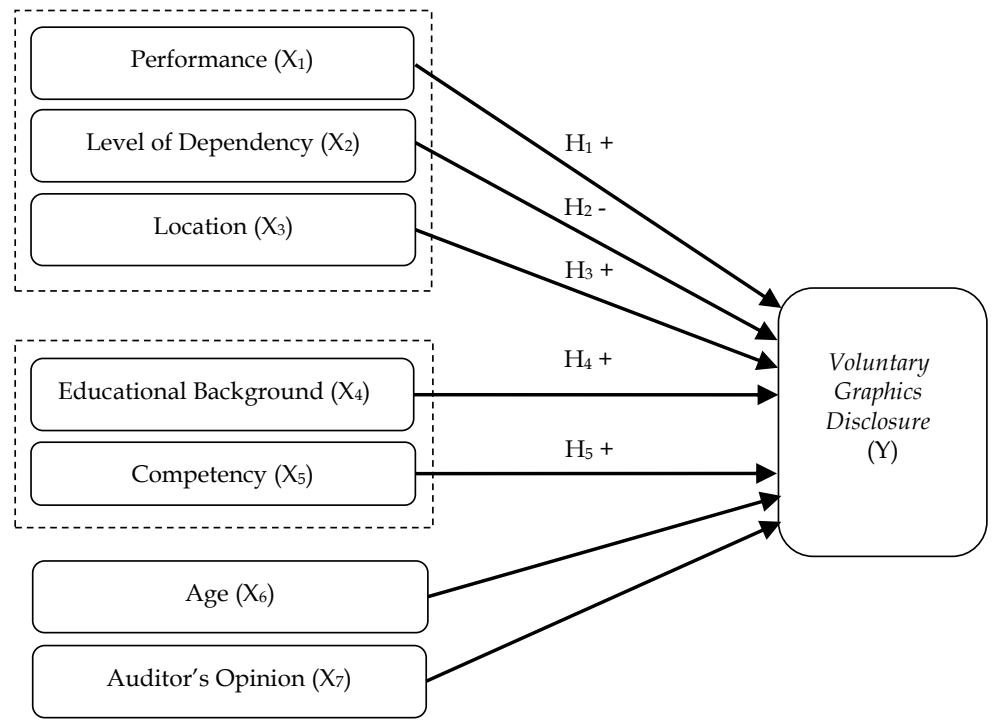

Figure 1 Conceptual Framework of the Research

Figure 1 shows the conceptual framework of this study. The measurement of variables is presented in Table 1.

Table 1 Measurement of Variables

\begin{tabular}{|c|c|c|}
\hline \multicolumn{2}{|l|}{ Variable } & \multirow{2}{*}{$\begin{array}{l}\text { Measurement } \\
\text { The number of graphics displayed in LKPD }\end{array}$} \\
\hline Dependent & $\begin{array}{l}\text { Voluntary Graph } \\
\text { Disclosure }\end{array}$ & \\
\hline \multirow[t]{4}{*}{ Independent } & $\begin{array}{l}\text { The performance of } \\
\text { the local government } \\
\text { Dependency level }\end{array}$ & $\begin{array}{l}\text { Value AA coded } 7, \text { A-coded } 6, \text { BB coded } 5, \text { B } \\
\text { coded } 4, C C \text { coded } 3, C \text { coded } 2 \text {, and D coded } 1 \\
\text { DAU divided by the total of the income }\end{array}$ \\
\hline & Geographical location & $\begin{array}{l}\text { Coded } 2 \text { for those located in Java and coded } 1 \text { for } \\
\text { those located on other islands. }\end{array}$ \\
\hline & $\begin{array}{l}\text { The education level of } \\
\text { regents and mayors }\end{array}$ & $\begin{array}{l}\text { Senior High School coded 1, D3 coded 2, S1 } \\
\text { coded 3, S2 coded 4, and S3 coded } 5\end{array}$ \\
\hline & $\begin{array}{l}\text { Competency of the } \\
\text { regents and mayors }\end{array}$ & $\begin{array}{l}\text { Coded } 1 \text { for economic and accounting education } \\
\text { background, and } 0 \text { for other educational } \\
\text { backgrounds. }\end{array}$ \\
\hline \multirow[t]{2}{*}{ Control } & $\begin{array}{l}\text { Ages of the local } \\
\text { government }\end{array}$ & $\begin{array}{l}\text { The accumulative years since the issue of the } \\
\text { regulation for the establishment of the local } \\
\text { government }\end{array}$ \\
\hline & $\begin{array}{l}\text { Type of the local } \\
\text { government }\end{array}$ & Coded 1 for cities and 0 for regencies \\
\hline
\end{tabular}


The data related to the performance was taken from the website of the ministry of empowerment of government apparatus and bureaucracy reform. On the other hand, the data concerning the location, age of, type of, education level, and educational background of the local government were taken from the website of the ministry of home affairs. The population of this research was 508 regional governments in Indonesia, which comprised 415 regencies and 93 cities. The purposive sampling technique was used to locate the sample of the study, that was taking into account certain criteria, such as (1) 2015 local government in Indonesian, (2) local government whose LKPD had been audited by the Audit Board of the Republic of Indonesia year 2015 and (3) local government that used graphics in the LKPD in 2015. Drawing on the purposive sampling, the sample size of this research was 187 regencies and cities with the following details (refer Table 2).

Table 2 Data Sample

\begin{tabular}{llc}
\hline No & Note & Number \\
\hline 1 & The number of regencies and cities in Indonesia in 2015 & 508 \\
2 & Local government without LKPD audited by the Indonesian Audit & $(9)$ \\
& $\begin{array}{l}\text { Board } \\
\text { Local government without using graphics in LKPD in 2015 }\end{array}$ & $(271)$ \\
4 & $\begin{array}{l}\text { Local government as an outlier } \\
\text { The number of samples in the regencies/cities }\end{array}$ & $(41)$ \\
\hline
\end{tabular}

Source: Website of the Ministry of Empowerment of Government Apparatus and Bureaucracy Reform 2017

\section{Empirical Analysis}

\subsection{The Practice of Voluntary Graphics Disclosure in Local Government Financial Statements}

The findings regarding the implementation of voluntary graphics disclosure in LKPD with regencies/cities in Indonesia as the sample showed that of the 499 LKPD, 228 used graphics to present information (44.88\%). In detail, the number consisted of 45 cities $(19.74 \%)$ and 183 regencies $(80.26 \%)$. The results showed that more cities than regencies used graphics. The rationale is that in general, the quality of human resources in city governments is better than in regency governments. Besides, the social control of the people in city governments is more critical than in district governments, hence affecting the information presentation practice in LKPD.

The implementation of voluntary graphics disclosure in LKPD can be categorised according to the regional zones of large islands in Indonesia to determine which regions implement the practice. The division follows the Master Plan for the Empowerment and Expansion of Development of the Indonesian Economy, known as MP3I. 
Based on the number of graphics presented according to the regions above, the regencies/cities located in Java were the leading local governments in using graphics in LKPD (449 graphics), followed by the regencies/cities in Sumatera, Sulawesi, Maluku-Papua, Kalimantan, and the fewest was by the local governments from Bali-Nusa Tenggara (refer to Table 3).

Table 3 Voluntary Graphics Disclosure According to the Regions

\begin{tabular}{lccc}
\hline Region & $\begin{array}{c}\text { Number of } \\
\text { Regencies/Cities }\end{array}$ & $\begin{array}{c}\text { Regencies/Cities } \\
\text { Presented Graph }\end{array}$ & Percentage \\
\hline Jawa & 113 & 66 & 58.41 \\
Bali - Nusa Tenggara & 41 & 19 & 46.34 \\
Maluku - Papua & 63 & 28 & 44.44 \\
Sulawesi & 81 & 34 & 41.98 \\
Kalimantan & 56 & 23 & 41.07 \\
Sumatera & 154 & 58 & 37.66 \\
Total & 508 & 228 & 44.88 \\
\hline
\end{tabular}

Source: Audited reports in LKPD year 2015

The information presented with graphics can be categorised into two types, namely financial and non-financial information. The regencies/cities preferred displaying financial information to non-financial information in their 2015 LKPD, with 1,126 and 184 graphics, respectively. Based on previous research, the private sector tends to use graphics to display key financial variables such as dividend per share (DPS), earnings per share (EPS), earnings, sales, and other financial or non-financial information (Dilla \& Janvrin, 2010; Guddal, 2016; Mather et al., 1996; Uyar, 2009; Warganegara et al., 2013). On the other hand, the government sector tends to display other key variables, which in this research were categorised into 10 key variables. This study found that the revenue variable (31.91\%) was the most presented using graphics in the LKPD.

Previous research divided the characteristics of information into good and bad in the risk disclosure in annual reports (Linsley \& Shrives, 2006). The research regarding graphics disclosure can also be categorised into good news and bad news (Jones, 2011). The current research categorised the characteristics of the information into positive, negative, and neutral information. A piece of information is regarded as positive if it shows an increase or betterment than in the past. On the other hand, a piece of information is considered negative if it shows a drop than previously, whereas neutral information refers to general information that does not show an increase or a drop. In this study, regencies/cities displayed positive information graphics the most with 561 graphics, followed by neutral information with 413 graphics and lastly, negative information with 336 graphics. 
Linsley and Shrives (2006) divided graphics into past and future information in displaying the risks of a company. The present study's results demonstrated that $99.85 \%$ of the information presented by regencies/cities in Indonesia was data on the past, while the remaining $0.15 \%$ was future information. The main types of graphics used in budgeting reports to deliver quantitative information are column, bar, line, pie, and pictorial (Beattie \& Jones, 1992). The current research categorised the types of graphics into column, line, pie, bar, area, scatter (XY), stock, surface, doughnut, bubble, and radar. This categorisation was made based on the types of graphics that can be presented using Microsoft Office. This study identified that the column graphic was the most frequently used to present information in the LKPD $(49.39 \%)$. The second and third most frequent graphics used were pie $(29.01 \%)$ and line $(17.25 \%)$, whereas stock, bubble, and radar types were never used to present information in the LKPD.

The financial report consists of the primary financial report section and narrative notes or reports of budgeting. The narrative report section usually presents information regarding the management report of resources usage, accountability of finance, and the performance realisation report. This study found that graphics were most frequently used to present information in Chapter II (financial obligation and macroeconomic), with 579 (44.20\%) graphics. On the other hand, no graphic was displayed in Chapter IV (accounting policy of regencies/cities). One of the benefits of using graphics to present information is to make the information presented more interesting. This research also followed the study of Guddal (2016), which classified graphics into "colour" or "black and white". The findings showed that colour graphics were more frequently employed than black and white graphics in presenting information in the LKPD of regencies/cities, with 1,143 (87.25\%) and $167(12.75 \%)$ graphics, respectively.

Table 4 Kolmogorov-Smirnov Test

\begin{tabular}{llc}
\hline & & Unstandardized Residual \\
\hline Observation & & 187 \\
Normal Parameters & Mean & 0.000 \\
& Std. Deviation & 2.515 \\
Most Extreme Difference & Absolute & 0.089 \\
& Positive & 0.089 \\
& Negative & -0.066 \\
Kolmogorov-Smirnov Z & & 1.222 \\
Asymp. Sig. (2-tailed) & & 0.101 \\
\hline
\end{tabular}

Before testing the hypotheses, this study performed all the classical assumption tests, namely the tests of normality, multicollinearity, heteroskedasticity, and autocorrelation. Kolmogorov-Smirnov and normal P- 
$\mathrm{P}$ (percent-percent) plot were used to test the normality of the regression models. Based on the output of the Kolmogorov-Smirnov test, the value of Asymp. Sig. exceeds 0.05 (refer to Table 4). The normal P-P (percent-percent) plot also shows a straight line that the existing points always follow and approaches the diagonal line. Hence, it can be concluded that the data contain no outliers and the residual value is normally distributed.

The issue of multicollinearity arises when two or more variables are highly correlated. Multicollinearity in this paper was detected by using Variance Inflated Factor (VIF). The VIF values for all the independent variables, as reported in Table 5, are far below the cut-off value of 10 and the tolerance values exceed 0.1 , thus confirming the absence of multicollinearity issue.

Table 5 Multicollinearity Test

\begin{tabular}{lccccccc}
\hline & \multicolumn{2}{c}{$\begin{array}{l}\text { Unstandardized } \\
\text { Coefficients }\end{array}$} & \multicolumn{2}{c}{$\begin{array}{l}\text { Stand. } \\
\text { Coeff. }\end{array}$} & & & \multicolumn{3}{c}{ Collinearity Statistics } \\
\cline { 2 - 7 } Variables & $\mathrm{B}$ & Std. Error & Beta & t-stats. & Sig. & Tolerance & VIF \\
\hline Perform & -0.352 & 0.265 & -0.107 & -1.327 & 0.186 & 0.715 & 1.398 \\
Depend & -2.620 & 1.206 & -0.156 & -2.172 & 0.031 & 0.900 & 1.111 \\
Locate & 1.557 & 0.494 & 0.251 & 3.150 & 0.002 & 0.726 & 1.378 \\
Edu & -0.433 & 0.205 & -0.154 & -2.116 & 0.036 & 0.877 & 1.140 \\
Compt & 1.932 & 0.405 & 0.342 & 4.767 & 0.000 & 0.900 & 1.111 \\
Age & -0.020 & 0.009 & -0.174 & -2.102 & 0.037 & 0.671 & 1.490 \\
Opinion & 0.270 & 0.163 & 0.121 & 1.651 & 0.101 & 0.863 & 1.159 \\
Constant & 5.108 & 1.415 & & 3.610 & 0.000 & & \\
\hline
\end{tabular}

Table 6 Durbin Watson Test

\begin{tabular}{ccccc}
\hline $\mathrm{R}$ & $\mathrm{R}$ Square & $\begin{array}{c}\text { Adjusted R } \\
\text { Square }\end{array}$ & $\begin{array}{c}\text { Std. Error of the } \\
\text { Estimate }\end{array}$ & Durbin-Watson \\
\hline 0.416 & 0.173 & 0.140 & 2.564 & 2.125 \\
\hline
\end{tabular}

Table 7 Glejser Test

\begin{tabular}{lccccccc}
\hline \multicolumn{3}{c}{$\begin{array}{c}\text { Unstandardized } \\
\text { Coefficients }\end{array}$} & \multicolumn{2}{c}{$\begin{array}{l}\text { Stand. } \\
\text { Coeff. }\end{array}$} & & & \multicolumn{3}{c}{ Collinearity Statistics } \\
\hline Variables & $\mathrm{B}$ & Std. Error & Beta & t-stats. & Sig. & Tolerance & VIF \\
\hline Perform & 0.033 & 0.154 & 0.018 & 0.213 & 0.832 & 0.715 & 1.398 \\
Depend & -0.227 & 0.700 & -0.025 & -0.324 & 0.746 & 0.900 & 1.111 \\
Locate & 0.080 & 0.287 & 0.024 & 0.278 & 0.781 & 0.726 & 1.378 \\
Edu & -0.215 & 0.119 & -0.142 & -1.809 & 0.072 & 0.877 & 1.140 \\
Compt & 0.275 & 0.235 & 0.090 & 1.170 & 0.244 & 0.900 & 1.111 \\
Age & -0.009 & 0.005 & -0.139 & -1.556 & 0.122 & 0.671 & 1.490 \\
Opinion & 0.083 & 0.095 & 0.069 & 0.880 & 0.380 & 0.863 & 1.159 \\
Constant & 2.559 & 0.821 & & 3.117 & 0.002 & & \\
\hline
\end{tabular}


Table 8 Results of Multiple Linear Regression Test

\begin{tabular}{lcccc}
\hline \multirow{2}{*}{ Variable } & \multicolumn{3}{c}{ Unstandardized Coefficients } & \\
\cline { 2 - 5 } Perform & $\mathrm{B}$ & Std. Error & t-stats. & Sig. \\
Depend & -0.352 & 0.265 & -1.327 & 0.186 \\
Locate & -2.620 & 1.206 & -2.172 & 0.031 \\
Edu & 1.557 & 0.494 & 3.150 & 0.002 \\
Compt & -0.433 & 0.205 & -2.116 & 0.036 \\
Age (control) & 1.932 & 0.405 & 4.767 & 0.000 \\
Opinion (control) & -0.020 & 0.009 & -2.102 & 0.037 \\
Constant & 0.270 & 0.163 & 1.651 & 0.101 \\
\hline$R^{2}$ & 5.108 & 1.415 & 3.610 & 0.000 \\
Adjusted R ${ }^{2}$ & 0.173 & & & \\
F-Value & 0.140 & & Asymp. Sig & 0.101 \\
\hline Note Perfor & 5.339 & DW & 2.125 \\
\hline
\end{tabular}

Notes: Perform=Performance, Depend=Level of Dependency, Locate=Location, Edu=Level of Education, Compt=Competency, Age=Age of Local Government, Opinion=Opinion of Badan Pemeriksa Keuangan Republik Indonesia (BPK-RI) of LKPD for the fiscal year of 2015.

The presence of autocorrelation in the errors of a regression model was detected using the Durbin-Watson test (D-W test) (refer to Table 6). The Durbin-Watson, $\mathrm{d}=2.125$, lies between the two critical values of $1.5<\mathrm{d}<2.5$. Therefore, there is no first-order linear auto-correlation in the multiple linear regression data. This paper used the Glejser test and scatterplot to detect heteroskedasticity. The Glejser test was conducted by regressing the absolute residual values of the independent variables (refer to Table 7). Based on the output coefficient, the obtained value of Sig. for all the independent variables exceed 0.05. In the scatterplot output, the spots appear diffused and do not form a clear specific pattern. Thus, it can be concluded that the regression model does not face the heteroskedasticity problem.

Table 8 above reports the adjusted R2 value of 0.140 , indicating that $14 \%$ of the variation in voluntary graphics disclosure in LKPD could be elaborated by the variables of Perform, Depend, Locate, Edu, Compt, Age, and Opinion. On the other hand, the remaining $86 \%$ was influenced by factors beyond this research model.

\subsection{Factors Influencing Voluntary Graphics Disclosure in Local Government Financial Statements}

Out of the five independent variables employed in this study, it was found that the location of the local government office and the competency of the local government had a significant positive correlation with voluntary graphics disclosure. On the other hand, the levels of dependency and education of the local government had a negative correlation with voluntary 
graphics disclosure, and the performance of the local government did not correlate with voluntary graphics disclosure in LKPD. The first hypothesis of this study, namely the performance of the local government has a positive influence on voluntary graphics disclosure in LKPD, was rejected. This is supported by the significance level of $18.6 \%$ for the performance of the local government, which exceeds the significance level set of $5 \%$. This result contradicts the findings of Mather et al. (1998), Ali and Saad (2006), Uyar (2009), Dilla and Janvrin (2010), Saha and Akter (2013), Andrenosa and Sukartha (2014), and Purwanto and Wikartika (2014). However, it supports the findings of prior research by Mather et al. (1996), Purwanto (2010), Saad et al. (2011), Uyar (2011), Warganegara et al. (2013), and Guddal (2016), which proved that the performance of a company does not influence the graphicsbased disclosure of information in the annual report.

Based on the empirical findings, the regencies/cities with good accountability as per the audit by the Ministry of Empowerment of Government Apparatus and Bureaucracy Reform did not influence the voluntary graphics disclosure in LKPD. This is due to the different reporting documents - Laporan Akuntanbilitas Kinerja Instansi Pemerintah (LAKIP) or Government Agency Performance Accountability Report and LKPDpossessed and analysed by two distinct parties. The LKPD are generated from the Sistem Informasi Manajemen Daerah (SIMDA) or Regional Financial Management Information System, while LAKIP is an output of the Sistem Akuntabilitas Kinerja Instansi Pemerintahan (SAKIP) or Government Agency Performance Accountability System, which is manually managed. Empirical findings revealed no correlation between the state auditing body's opinion of the financial report and the scoring resulted from the evaluation of LAKIP Kementerian/Lembaga (K/L) (Asmoko, 2015). The reason could be attributed to the absence of an integrated accounting system between the financial report and LAKIP K/L. As a result, the documents generated are different.

The second hypothesis of the present study, namely the level of dependency of the local government negatively affects the voluntary graphics disclosure in LKPD, was accepted. The hypothesis testing result showed that the variable Depend obtained a beta coefficient of -2.620 at the significance level of $3.1 \%$, which is lower than the significance level of $5 \%$. The result contradicts the previous research by Robbins and Austin (1986), Puspita and Martani (2012), and Martani et al. (2014). However, it agrees with other studies that found a negative correlation between the level of dependency of the local government and the voluntary disclosure in LKPD (Patrick, 2007; Setyaningrum \& Syafitri, 2012; Hendriyani \& Tahar, 2015).

The empirical finding showed that the local governments with a higher level of dependency did not apply more voluntary graphics disclosure in LKPD. The reason is that the more dependent a certain region is, the more it 
shows its financial constraints. The Vice Minister of the Finance Ministry, Mardiasmo, stated that the DAU was frequently used to fund employees' needs (Baihaqi, 2017, accessed on 21 May 2017). The data derived from the Directorate General of the Ministry of Finance showed that, on average, the spending was $46 \%$ for employees. Therefore, local governments were not able to innovate. Innovation or reform in the public sector is undoubtedly determined by the available resources in the economy (García-Sánchez et al., 2013). One of the local governments' innovations in the financial report is using graphics to disclose information in LKPD.

The third hypothesis of this study, namely the geographical location of the local government office is positively correlated to the voluntary graphics disclosure in LKPD, was accepted. This hypothesis testing result showed that the variable Locate reported a beta coefficient of 1.557 at the significance of level $0.2 \%$, which is far below the significance level of $5 \%$. This result conflicts with the previous research findings of Pujiyanti (2011) and Suhardjanto and Yulianingtyas (2011). However, it is in line with the research findings of Arifin et al. (2016) and Narulitasari (2016).

From the agency theory perspective, the correlation between the geographical location of the local government office and the information disclosure in LPKD can be explained by the agent's position that influences the capacity and willingness to disclose the information. The regional governments in Java, which enjoys better education quality, more complete facilities, and a stable economy, are able to employ better quality human resources. Therefore, high-quality human resources determine better, more innovative, and high-quality information disclosure in LKPD.

The fourth hypothesis of this research, namely the education level of the local government correlates positively with the voluntary graphics disclosure in LKPD, was rejected. The hypothesis testing result showed that Edu obtained a beta coefficient of -0.433 at the significance level of $3.6 \%$. This research finding contradicts the previous research of Hambrick and Mason (1984), Wiersema and Bantel (1992), Finkelstein and Hambrick (1996), Seeba et al. (2009), and Bamber and McMeeking (2010). The result demonstrated that the education level of the local government affected the voluntary graphics disclosure in LKPD negatively. It means that the higher the education level of the local government, the less information is presented in the form of graphics. Based on the agency theory, the local government (agent) with a higher education degree will be able to display different graphics for information disclosure in LKPD. However, there is a moral hazard issue of state officers with higher education. This is proven by the data taken from the Corruption Eradication Commission, which showed that out of 600 corruptors, 200 had a master degree, followed by an undergraduate degree, and 40 with a doctorate (Ramdhani, 2016, accessed on 21 Mei 2017). 
The fifth hypothesis, which is the competency of the local government head correlates positively to the voluntary graphics disclosure in LKPD, was accepted. This was evidenced by the beta coefficient of Compt of 1.932 at the significance level of $0 \%$, which is below the determined significance level of $5 \%$. This research finding contradicts the previous findings of Haniffa and Cooke (2002) and Setyaningrum and Syafitri (2012). However, it confirms the previous research findings of Bamber et al. (2010), Kharis and Suhardjanto (2012), and Lewis et al. (2013). The empirical finding demonstrated that the education background of the local government head affected the voluntary graphics disclosure in LKPD positively. This is because the local government head with an economic and accounting education background is better able to understand the financial report. Consequently, the local government head knows better how to present the accounting information in a straightforward way for users to interpret.

\section{Conclusion}

Based on the statistical analyses and discussion, this study concludes that the practice of voluntary graphics disclosure in LKPD in Indonesia is not widespread. The number of graphics presented in the sampled LKPD for the year 2015 was 1,310. A higher proportion of the cities $(49.45 \%)$ than the regencies $(44.85 \%)$ applied graphics. This study also concludes that the performance of the local government does not influence the voluntary graphics disclosure in LKPD. This notion is supported by the data on local governments (regencies and cities) taken from the Ministry of Empowerment Apparatus and Bureaucratic Reform, which show that the level of performance does not determine the number of graphics used in LKPD.

The study also concludes that the level of dependency of the local government influences voluntary graphics disclosure negatively. The more dependent the regencies or cities, the less they present information using graphics, and the less able they are to innovate in LKPD. Further, the geographical location of the local government office is concluded to have a positive impact on the voluntary graphics disclosure in LKPD. The local governments in Java presented more information using graphics than those from other islands. The graphical presentation of information in LKPD needs better human resources capacities so that the information displayed can be interpreted easily and is not distorted. This study also concludes that the education level of the local government head has a negative correlation to the voluntary graphics disclosure in LKPD. While a high level of education determines one's professionalism, moral hazard within the local governments in Indonesia has led to misuse of power.

This is proven by the data derived from the Corruption Eradication Commission, which revealed that $40 \%$ of the corruptors had a higher 
education degree (Ramdhani, 2016, accessed on 21 May 2017). Further, this study found a positive correlation between the competency of the local government head and the voluntary graphics disclosure in LKPD. Local government managers with an economic or accounting academic background are better able to interpret and implement accounting standards. With economic competence, managers can avoid errors in accounting (Hambrick \& Mason, 1984). The local government managers with an economic and accounting education background also know better how to present information more accurately.

This study contributes to the literature by exploring the approaches used by researchers in public sector disclosure. This systematic review has highlighted the importance of the content analysis technique as the most dominant method to investigate and measure the information disclosed in public sector annual reports. This study also contributes to the Government Accounting Standard Committee of central and local governments. Despite the numerous benefits offered by graphics in information presentation, its use remains scarce at the regional level. Hence, the State Accounting Standard Committee should consider the format for displaying information in the financial report. Moreover, gaps in various fields have led to differences in human resources quality, thus affecting the quality of financial statement presentation. Due to economic disparities, the level of dependency of regional governments influences the presentation of information in LKPD. The absence of accountability demands by the central government as the DAU provider has led to a lack of attention among the local governments to the quality of LKPD. Therefore, the central government needs to reexamine the DAU accountability mechanism.

There are several limitations to the present study that may affect the empirical findings. First, this research only focused on the voluntary graphics disclosure of regencies/cities. Therefore, the sample was limited to the use of graphics in financial reports at the city/regional level. Second, this research analysed the data for the year 2015 because the LKPD for 2015 are the initial reports documented based on Government Regulation No. 71 Year 2010. There is no data on 2016 LKPD, which have been audited by the Indonesian Supreme Auditing Body.

\section{References}

Agustijanti, D. (2016). Studi Eksplorasi Pemanfaatan Laporan Keuangan Pemerintah Daerah untuk Pengambilan Keputusan Ekonomi pada Pemerintah Kabupaten Klaten. (Doctoral dissertation, Universitas Gadjah Mada).

Ali, A. M., \& Saad, R. A. J. (2006). Impression management: the case of Malaysian financial graphs. International Journal of Management Studies, 13(2), 41-74.

Amer, T. (2005). Bias due to visual illusion in the graphical presentation of accounting information. Journal of Information Systems, 19(1), 1-18. 
Andrenossa, G., \& Sukartha, I. M. (2014). Hubungan pengungkapan informasi grafik key financial variable dengan perubahan kinerja dalam laporan tahunan perusahaan yang terdaftar di BEI. Jurnal Buletin Studi Ekonomi, 19(2), 119-128.

Arifin, J., Tower, G., \& Porter, S. (2015). Finacial reporting compliance in Indonesian Local governments: Mimetic pressure dominates. Jurnal Akuntansi dan Auditing Indonesia, 19(1), 68-84.

Asmoko, H. (2015). Korelasi Opini Audit BPK atas LKKL dengan Hasil Evaluasi Lakip K/L. L, Balai Diklat Kepemimpinan, BPPK Kementerian Keuangan, Jakarta.

Bantel, K. A., \& Jackson, S. E. (1989). Top management and innovations in banking: Does the composition of the top team make a difference? Strategic Management Journal, 10(S1), 107124. https://doi.org/10.1002/smj.4250100709

Baihaqi, B. (2017). Wamenkeu Soroti Rendahnya Pemanfaatan Laporan Keuangan. Neraca.co.id. $\quad$ Retrieved $21 \quad$ May 2017, from http://www.neraca.co.id/article/80558/wamenkeu-soroti-rendahnya-pemanfaatanlaporan-keuangan.

Bamber, L. S., Jiang, J. X., \& Wang, I. Y. (2010). What's my style? The influence of top managers on voluntary corporate financial disclosure. The Accounting Review, 85(4), 11311162. https:// doi.org/10.2308/accr.2010.85.4.1131

Bamber, M., \& McMeeking, K. (2010). An examination of voluntary financial instruments disclosures in excess of mandatory requirements by UK FTSE 100 non-financial firms. Journal of Applied Accounting Research, 11(2), 133-153. https://doi.org/10.1108/09675421011069504

Bandari, H., \& Rohman, A. (2011). Pengaruh Penyajian Laporan Keuangan Daerah Dan Aksesibilitas Laporan Keuangan Terhadap Penggunaan Informasi Keuangan Daerah (Studi Pada Kabupaten Eks Karesidenan Banyumas). (Doctoral dissertation, Universitas Diponegoro).

Beattie, V., \& Jones, M. (1994). An Empirical study of graphical format choices in charity annual reports. Financial Accountability and Management, 10(3), 215-236. https:// doi.org/10.1111/j.1468-0408.1994.tb00230.x

Beattie, V., \& Jones, M. J. (1992). The use and abuse of graphs in annual reports: a theoretical framework and empirical study. Accounting and Business Research, 22(88), 291-303. http://dx.doi.org/10.1080/00014788.1992.9729446

Beattie, V., \& Jones, M. J. (1997). A comparative study of the use of financial graph in the corporate annual reports of major U.S. and U.K. companies. Journal of International Financial Management and Accounting, 8(1), 33-68. https://doi.org/10.1111/1467646X.00016

Beattie, V., \& Jones, M. J. (2002). Measurement distortion of graphs in corporate reports: An experimental study. Accounting, Auditing \& Accountability Journal, 15(4), 546-564. https:// doi.org/10.1108/09513570210440595

Beattie, V., \& Jones, M. J. (2008). Corporate reporting using graphs: a review and synthesis. Journal of Accounting Literature, 27, 71-110.

Chan, S. Y. (2001). The use of graphs as decision aids in relation to information overload and managerial decision quality. Journal of Information Science, 27(6), 417-425. https://doi.org/10.1177\%2F016555150102700607

Diamond, J. (2002). Performance budgeting-is accrual accounting required? IMF Working Paper. Fiscal Affairs Department.

Dilla, W. N., \& Janvrin, D. J. (2010). Voluntary disclosure in annual reports: The association between magnitude and direction of change in corporate financial performance and graph use. Accounting Horizons, 24(2), 257-278. https://doi.org/10.2308/acch.2010.24.2.257 
Finkelstein, S., \& Hambrick, D. C. (1996). Strategic leadership: Top executives and their effects on organizations. Australian Journal of Management, 22(2), 221-224. https://doi.org/10.1177\%2F031289629702200205

Frownfelter-Lohrke, C., \& Fulkerson, C. L. (2001). The incidence and quality of graphics in annual reports: An international comparison. The Journal of Business Communication (1973), 38(3), 337-357. https:/ / doi.org/10.1177\%2F002194360103800308

Fulkerson, C. L., Pitman, M. K., \& Frownfelter-Lohrke, C. (1999). Preparing financial graphics: Principles to make your presentations more effective. The CPA Journal, 69(6), 28-33.

García-Sánchez, I.-M., Frías-Aceituno, J.-V., \& Rodríguez-Domínguez, L. (2013). Determinants of corporate social disclosure in Spanish local governments. Journal of Cleaner Production, 39, 60-72. https:// doi.org/10.1016/i.jclepro.2012.08.037

Guddal, T. (2016). Graph usage in annual reports, evidence from Norwegian listed companies (Doctoral dissertation).

Hambrick, D. C., \& Mason, P. A. (1984). Upper echelons: The organization as a reflection of its top managers. Academy of Management Review, 9(2), 193-206. https://doi.org/10.2307/258434

Haniffa, R. M., \& Cooke, T. E. (2002). Culture, corporate governance and disclosure in Malaysian corporations. Abacus, 38(3), 317-349. https:// doi.org/10.1111/1467-6281.00112

Hendriyani, R., \& Tahar, A. (2015). Analisis faktor-faktor yang mempengaruhi tingkat pengungkapan laporan keuangan pemerintah provinsi di Indonesia. Jurnal Bisnis dan Ekonomi (JBE), 22 (1), 25-33.

Hilmi, A. Z., \& Martani, D. (2012). Analisis faktor-faktor yang mempengaruhi tingkat pengungkapan laporan keuangan pemerintah provinsi. Simposium Nasional Akuntansi $\mathrm{XV}, 20$.

Hitt, M. A., \& Tyler, B. B. (1991). Strategic decision models: Integrating different

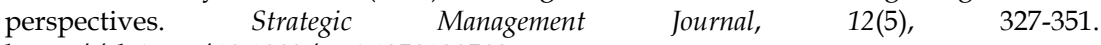
https://doi.org/10.1002/smj.4250120502

Huang, S. Y., Chung, Y.-H., \& Cheng, W.-W. (2008). The effects between numerical tabulations and graphs of financial information on the judgment of investors. Review of Business Information Systems, 12(4), 41-56. http:// dx.doi.org/10.19030/rbis.v12i4.4344

Indonesia, P.R. (1974). Undang-Undang Republik Indonesia Nomor 5 Tahun 1974 tentang Pokok-Pokok Pemerintahan di Daerah

Indonesia, P.R. (1999). Undang-Undang Republik Indonesia Nomor 22 Tahun 1999 tentang Pemerintahan Daerah

Indonesia, P.R. (2003). Undang-Undang Republik Indonesia Nomor 17 Tahun 2003 tentang Keuangan Negara

Indonesia, P. R. (2004). Undang-Undang Republik Indonesia Nomor 1 Tahun 2004 tentang Perbendaharaan Negara.

ndonesia, P.R. (2004). Undang-Undang Republik Indonesia Nomor 15 Tahun 2004 tentang Pemeriksaan Pengelolaan dan Tanggung Jawab Keuangan Negara

Indonesia, P.R. (2004). Undang-Undang Republik Indonesia Nomor 33 Tahun 2004 tentang Perimbangan Keuangan antara Pemerintah Pusat dan Pemerintahan Daerah

Indonesia, R. (2008). Peraturan Pemerintah Republik Indonesia Nomor 8 Tahun 2008 tentang Pelaporan Keuangan dan Kinerja Instansi Pemerintah

Indonesia, R. (2010). Peraturan Pemerintah Nomor 71 Tahun 2010 Tentang Standar Akuntansi Pemerintahan. Jakarta (ID): Sekretaris Negara.

Indonesia, P. R. (2014). Undang-Undang Nomor Republik Indonesia 23 Tahun 2014 tentang Pemerintahan Daerah 
Indonesia, R. (2014). Peraturan Presiden Republik Indonesia Nomor 29 Tahun 2014 tentang Sistem Akuntabilitas Kinerja Instansi Pemerintah. Lembaran Negara RI Tahun, 80.

Indonesia, P.R. (2015). Undang-Undang Republik Indonesia Nomor 9 Tahun 2015 tentang Pemerintahan Daerah

Indonesia, P.R. (2016). Undang-Undang Republik Indonesia Nomor 10 Tahun 2016 tentang Perubahan Kedua atas Undang-Undang Nomor 1 Tahun 2015 tentang Penetapan Peraturan Pemerintah Pengganti Undang-Undang Nomor 1 Tahun 2014 tentang Pemilihan Gubernur, Bupati, dan Walikota Menjadi Undang-Undang

Ingram, R. W., \& DeJong, D. V. (1987). The Effect of Regulation on Local Government Disclosure Practices. Journal of Accounting and Public Policy, 6(4), 245-270. https:// doi.org/10.1016/S0278-4254(87)80002-9

Jensen, M. C., \& Meckling, W. H. (1976). Theory of the firm: Managerial behavior, agency costs and ownership structure. Journal of Financial Economics, 3(4), 305-360. https://doi.org/10.1016/0304-405X(76)90026-X

Jones, M. J. (2011). The nature, use and impression management of graphs in social and $\begin{array}{lll}\text { environmental accounting. } & \text { Accounting }\end{array}$ https:// doi.org.10.1016/j.accfor.2011.03.002

Kharis, A., \& Suhardjanto, D. (2012). Corporate governance dan ketaatan pengungkapan wajib pada badan usaha milik negara. Jurnal Keuangan dan Perbankan, 16(1), 37-44.

Kieso, D. E., Weygandt, J. J., \& Warfield, T. D. (2010). Intermediate Accounting IFRS Edition. New York: John Wiley \& Sons. Inc.

Kimberly, J. R., \& Evanisko, M. J. (1981). Organizational innovation: The influence of individual, organizational, and contextual factors on hospital adoption of technological and administrative innovations. Academy of Management Journal, 24(4), 689-713. https://doi.org/10.5465/256170

Lesmana, S. I. (2010). Pengaruh Karakteristik Pemerintah Daerah terhadap Tingkat Pengungkapan Wajib di Indonesia. (Doctoral dissertation, UNS (Sebelas Maret University)).

Lewis, B. W., Walls, J. L., \& Dowell, G. W. S. (2014). Difference in degrees: CEO characteristics and firm environmental disclosure. Strategic Management Journal, 35(5), 712-722. https://doi.org/10.1002/smj.2127

Linsley, P. M., \& Shrives, P. J. (2006). Risk reporting: A study of risk disclosures in the annual reports of UK companies. The British Accounting Review, 38(4), 387-404. https://doi.org/10.1016/j.bar.2006.05.002

Litvack, J., \& Seddon, J. (2020). Decentralization Briefing Notes. Www1.worldbank.org. $\begin{array}{llll}\text { Retrieved } \quad 30 & \text { September } & \text { 2020, }\end{array}$ http://www1.worldbank.org/publicsector/LearningProgram/Decentralization/Briefin gNotes.pdf.

Mahardini, N. Y. (2014). Pengaruh Karakteristik Kepala Daerah Terhadap Kinerja Keuangan Pemerintah Daerah di Indonesia dengan Lokasi Pemerintahan, Jumlah Populasi dan Besar APBD sebagai Variabel Kontrol. (Doctoral Dissertation, Universitas Sebelas Maret Surakarta).

Mardiasmo. (2006). Pewujudan Transparansi dan Akuntabilitas Publik Melalui Akuntansi Sektor Publik: Suatu Sarana Good Governance. Jurnal Akuntansi Pemerintahan, 2(1).

Martani, D., Fitriasari, D., \& Annisa. (2014). Financial and performance transparency on the local government websites in Indonesia. Journal of Theoretical and Applied Information Technology, 60(3), 504-516.

Martani, D., \& Lestari, A. (2010). Local Government Financial Statement Disclosure in Indonesia. In Annual Meeting and Conference Asian Academic Accounting Association (AAAA). 
Mather, P., Ramsay, A., \& Serry, A. (1996). The use and representational faithfulness of graphs in annual reports: Australian evidence. Australian Accounting Review, 6(2), 56-63. https://doi.org/10.1111/j.1835-2561.1996.tb00017.x

Mather, P., Ramsay, A., \& Steen, A. (2000). The use and representational faithfulness of graphs in Australian IPO prospectuses. Accounting, Auditing \& Accountability Journal, 13(1), 65-83. https://doi.org/10.1108/09513570010316144

Martínez-Ferrero, J., Rodríguez-Ariza, L., García-Sánchez, I. M., \& Cuadrado-Ballesteros, B. (2018). Corporate social responsibility disclosure and information asymmetry: The role of family ownership. Review of Managerial Science, 12(4), 885-916. https://doi.org/10.1007/s11846-017-0232-5

Martínez-Ferrero, J., Ruiz-Cano, D., \& García-Sánchez, I. M. (2016). The causal link between sustainable disclosure and information asymmetry: The moderating role of the stakeholder protection context. Corporate Social Responsibility and Environmental Management, 23(5), 319-332. https:// doi.org/10.1002/csr.1379

Mulyana, B. (2006). Pengaruh Penyajian Neraca Daerah dan Aksesibilitas Laporan Keuangan terhadap Transparansi dan Akuntabilitas Pengelolaan Keuangan Daerah. (Doctoral dissertation, Universitas Gadjah Mada).

Narulitasari, D. (2016). Pengungkapan Intellectual Capital dan Karakteristik Pemerintah Daerah Kabupaten/Kota di Indonesia. (Doctoral dissertation, UNS (Sebelas Maret University)).

Osahon, O. K. (2008). The Effect of Information Visualization on Financial Reports. (Doctoral dissertation, Master Thesis, Hanken-School of Economics)

Patrick, P. A. (2007). The Determinants of Organizational Innovativeness: The Adoption of GASB 34 in Pennsylvania Local Government. (Doctoral dissertation, Pennsylvania State University)

Pennington, R., \& Tuttle, B. (2009). Managing impressions using distorted graphs of income and earnings per share: The role of memory. International Journal of Accounting Information Systems, 10(1), 25-45. https://doi.org/10.1016/j.accinf.2008.10.001

Peters, G. F., \& Romi, A. M. (2013). Does the voluntary adoption of corporate governance mechanisms improve environmental risk disclosures? Evidence from greenhouse gas emission accounting. Journal of Business Ethics, 125(4), 637-666. https://doi.org/10.1007/s10551-013-1886-9

Permendagri. (2011). Perubahan Kedua atas Peraturan Menteri Dalam Negeri Nomor 13 Tahun 2006 tentang Pedoman Pengelolaan Keuangan Daerah.

Prayitno, S. (2012). Pengaruh Karakteristik Keuangan Pemerintah Daerah dan Karakteristik Kepala Daerah terhdapa Kinerja Keuangan Pemerintah Daerah. (Doctoral dissertation, UNS (Sebelas Maret University)).

Probohudono, A. N., Tower, G., \& Rusmin, R. (2013). Risk disclosure during the global financial crisis. Social Responsibility Journal, 9(1), 124-136. https://doi.org/10.1108/17471111311307859

Pujiyanti, U. (2011). Indonesian Local Government Compliance of Mandatory DIsclosure on Governmental Accounting Standard (Doctoral dissertation, UNS (Sebelas Maret University)).

Purwanto, A. (2010). Analisis determinan graphical information disclosure sebagai pendukung prinsip transparansi perusahaan publik di Indonesia. Jurnal Akuntansi dan Auditing, 7(1), 1-16.

Purwanto, E., \& Wikartika, I. (2014). Analisis voluntary disclosure perusahaan telekomunikasi di BEI. Jurnal Neo-Bis, 8(2), 101-115. 
Puspita, R., \& Martani, D. (2012). Analisis pengaruh kinerja dan karakteristik PEMDA terhadap tingkat pengungkapan dan kualitas informasi dalam website PEMDA. Universitas Indonesia

Ramdhani, J. (2016). KPK: Koruptor Mayoritas Berpendidikan Tinggi, 32 Persennya Kader Parpol. Retrieved 21 May 2017, from https://news.detik.com/berita/d-3353677/kpkkoruptor-mayoritas-berpendidikan-tinggi-32-persennya-kader-parpol

Rasidah, \& Chairina. (2010). Pengaruh Karakteristik Perusahaan dan Struktur Kepemilikan terhadap Pengungkapan Tanggung Jawab Sosial (Social Disclosure) (Studi Empiris pada Perusahaan Manufaktur yang Listing di Bursa Efek Indonesia). Jurnal Ekonomi Pembangunan, Manajemen dan Akuntansi, 9(3), 275-286.

Rezaee, Z., \& Porter, G. L. (1993). Can the annual report be improved? Review of Business, 15(1), 38-41.

Robbins, W. A., \& Austin, K. R. (1986). Disclosure quality in governmental financial reports: An assessment of the appropriateness of a compound measure. Journal of Accounting Research, 24(2), 412-421. https:// doi.org/10.2307/2491145

Ruchti, U. and Wasserman, N. (1983). Public companies have to view themselves as publishers: The annual report is a periodical. Public Relations Quarterly, Winter, 9-13.

Saad, R. A. J., Yahya, M. A., \& Hussain, M. H. M. (2011). The relationship between performance and graphic presentation in unit trusts' annual reports: Malaysian Evidence. Journal of Business Management and Accounting, 1(1), 1-15.

Saha, A. K., \& Akter, S. (2013). Corporate governance and voluntary disclosure practices of financial and non-financial sector companies in Bangladesh. Journal of Applied Management Accounting Research, 11(2), 45-61.

Sanjaya, I. D. N. K. P., Sujana, E., \& Sulindawati, N. L. G. E. (2014). Pengaruh Penyajian Laporan Keuangan dan Aksesibilitas Laporan Keuangan Daerah terhadap Penggunaan Informasi Keuangan Daerah (Studi Pada Satuan Kerja Perangkat Daerah Kabupaten Buleleng). Jurnal Ilmiah Mahasiswa Akuntansi Undiksha, 2(1).

Saptodewo, F. (2016). Desain infografis sebagai penyajian data menarik. Jurnal Desain, 1(3), 193-218.

Saputra, A. R. (2012). Kajian Penggunaan informasi keuangan daerah. Accounting Analysis Journal, 1(2), 1-6. https:// doi.org/10.15294/aaj.v1i2.653

Schiavo-Campo, S., \& Tommasi, D. (1999). Managing Government Expenditure. Manila: Asian Development Bank.

Sebaa, A. A., Wallace, J., \& Cornelius, N. (2009). Managerial characteristics, strategy and performance in local government. Measuring Business Excellence, 13(4), 12-21. https:// doi.org/10.1108/13683040911006756

Setyaningrum, D., \& Syafitri, F. (2012). Analisis pengaruh karakteristik pemerintah daerah terhadap tingkat pengungkapan laporan keuangan. Jurnal Akuntansi dan Keuangan Indonesia, 9(2), 154-170

Setyowati, L. (2016). Determinan yang mempengaruhi pengungkapan laporan keuangan pemerintah daerah. Esensi: Jurnal Bisnis dan Manajemen, 6(1), 45-62.

Smith, L. M., \& Bain, C. E. (1987). Computer Graphics for Today's Accountant [2]. The CPA Journal, 57(2), 18.

Steccolini, I. (2004). Is the annual report an accountability medium? An empirical investigation into Italian local governments. Financial Accountability $\mathcal{E}$ Management, 20(3), 327-350. https://doi.org/10.1111/j.0267-4424.2004.00389.x

Steinbart, P. J. (1989). The auditor's responsibility for the accuracy of graphs in annual reports: Some Evidence of the need for additional guidance. Accounting Horizons, 3(3), $60-70$. 
Suhardjanto, D., \& Miranti, L. (2009). Indonesian Enviromental Reporting Index dan Karakteristik Perusahaan. Jurnal Akuntansi dan Auditing Indonesia, 13(1).

Suhardjanto, D., \& Permatasari, N. D. (2010). Pengaruh corporate governance, etnis dan latar belakang pendidikan terhadap environmental disclosure: Studi empiris pada perusahaan listing di Bursa Efek Indonesia. KINERJA, 14(2), 151-164.

Suhardjanto, D., \& Yulianingtyas, R. R. (2011). Pengaruh karakteristik pemerintah daerah terhadap kepatuhan pengungkapan wajib dalam laporan keuangan pemerintah daerah (Studi empiris pada Kabupaten/Kota di Indonesia). Jurnal Akuntansi \& Auditing, 8(1), 3042.

Sullivan, J.J. (1988). Financial presentation format and managerial decision making: tables versus graphs. Management Communication Quarterly, 2(2), 194-216.

Tim Presiden, R. I. (2016). Tahun Pemerintahan JOKOWI-JK Akselerasi Mewujudkan Indonesia Sentris. Jakarta: Kantor Staf Presiden Republik Indonesia.

Uyar, A. (2009). An analysis of graphic disclosure in annual reports: the case of Turkey. Managerial Auditing Journal, 24(5), 423-444. https:/ / doi.org/10.1108/02686900910956793

Uyar, A. (2011). Firm characteristics and voluntary disclosure of graphs in annual reports of Turkish listed companies. African Journal of Business Management, 5(17), 7651-7657.

Wally, S., \& Baum, J. R. (1994). Personal and structural determinants of the pace of strategic decision making. Academy of Management Journal, 37(4), 932-956. https:// doi.org/10.2307/256605

Warganegara, D. L., Hutagaol, Y. R. I., \& Bachrumsyah, T. F. (2013). The incidence and quality of financial graphics in Indonesian IPO prospectuses. Jurnal Keuangan dan Perbankan, 17(2), 169-180.

Wiersema, M. F., \& Bantel, K. A. (1992). Top management team demography and corporate strategic change. The Academy of Management Journal, 35(1), 91-121. https:// doi.org/10.2307/256474

Wilson, K., \& Stanton, P. (1996). Pretty pictures, damned lies, and graphs in reports. Australian Accountant, 66(5), 42-43.

Zimmerman, J. L. (1977). The municipal accounting maze: An analysis of political incentives. Journal of Accounting Research, 15, 107-144. https:/ / doi.org/10.2307/2490636 